\title{
TYPOLOGY OF HISTORICAL HOUSES IN MUZAFFARID ERA: CASE STUDY OF ARDAKAN CITY, YAZD, IRAN
}

\author{
Mansoure Dormohamadi $1, *$ \\ ${ }^{1}$ Master of Architecture, Art and Architecture University of Yazd, Yazd, Iran - Dormohamadi_m@yahoo.com
}

Commission II - WG II/8

KEY WORDS: Historical House, Muzaffarid Era, Typology, Iwan, Ardakan

\begin{abstract}
:
MOZAFFARIDS established the Mozaffarid dynasty in Yazd, Iran. This era witnessed a development in architectural and decorative features of Yazd buildings. Ardakan, in particular, enjoyed a period of prosperity in the 14th century, which led to a flourishing growth of architectural production. The present article uses a descriptive-analytical and historical-comparative method to investigate the typology of 12 historical houses of Ardakan city in the Muzaffarid era. By using literature review and field studies, four of these houses have been studied in detail in terms of architectural and decorative features and construction methods. The results of the study show that Mozaffarid houses in Ardakan have certain and distinguishable patterns and follow a general rule. Main Iwan as an outstanding feature in Mozaffarid houses, as well as a central courtyard and a Soffeh in front of the Iwan, repeated in all houses and other parts, are formed in their surroundings. With the change in the location of the main Iwan in the northern or southern part of the central courtyard and the fact that whether or not there is a garden, significant differences in organization and the quality of spaces have been made. Mozaffarid houses in Ardakan can be described as two main types each of which can be divided into two subcategories based on the Iwan position. The knowledge of typological characteristics of these historical architecture needs to be gathered to preserve the built heritage and a comprehensive document is essential for the preservation and conservation of the houses.
\end{abstract}

\section{INTRODUCTION}

Historical vernacular housing has always been designed with respect to nature; incorporating and reflecting the local lifestyle and cultural conditions as well as being a direct expression of the state of know-how of construction techniques, the availability of local construction materials and local climatic (Turner, 1976). Today, historical settlements and their rather homogeneous housing typologies can still be found and studied in the case of preserved contexts and buildings in Iran. Iran is a rich country in vernacular architecture. Despite the losses due to frequent earthquakes and large-scale planning projects, historical towns still contain thousands of houses. Until recently, there have been little attempts to record Iranian vernacular buildings; even less to analyze or explain their architecture. The houses before the Safavid era have been the most unknown ones in comparison to other eras. So, the present study aims to investigate the historical houses in the Muzaffarid era, which is one of the most significant eras of Yazd history. Ardakan is one of the oldest cities of Iran containing a lot of old houses in its historical context. Its historical houses, having remained largely undocumented, are the most important samples to represent the lifestyle of the past. In Ardakan County, some elegant samples of Muzaffarid houses have been identified needing detailed investigation. This article aims to investigate the typology of Ardakan historical houses in the Mozaffarid era. In this regard, the spatial organization of 12 historical houses located in the historical context of Ardakan was studied four of which are elaborated in terms of architectural, decorative features, and construction methods. These buildings have features, which are the same in most samples and are unique to the architecture of the era; while there is considerable variation, spatially and physically, from one house to another. Thus, this paper is supposed to classify the historical houses of Ardakan based on the typological method.

\subsection{Muzaffarids and Architectural Legacy in Yazd}

The Muzaffarids (Āl-e Mozaffar) is a Sunni family coming to power in central Iran in the fourteenth century and the family of governors of Yazd under the Il-Khanids (1256-1335/1353), who expanded their domain after the collapse of the Il-Khanid power and established the Mozaffarid dynasty in Yazd, Kerman, Fars, and Erāq-e Ajam. The Muzaffarids, enduring until its destruction by Timur (Tamerlane) in 795/1393, originated as an Arab family settling in Khorasan. They stayed in Khorasan up until the Mongol invasion of that province when they fled to Yazd. Serving under the Il- Khanids, they gained prominence when Sharaf al-Din Muzaffar was made the governor of Maybod (Wing, 2014; New World Encyclopedia contributors, 2009). Manz says that the Muzaffarids "are remembered as cultural patrons" (Manz, 2007). Muzaffarid era in Yazd has been one of the most important eras in the history of the region as it was for the first time that a dynasty ruled the southern and central parts of Iran for more than a half-century (Mirhosseini, 1993). In this era, most of the artists and scientists settled in Yazd to avoid Mongol invasion and to pursue their academic attempts. Partial security and peace in Yazd and the attention of Il-Khanids to Muzaffarids led to the high scientific artistic interaction between these two governments. Moreover, the collection of scientists and artists in Yazd, as well as communication about architectural techniques and decorations, led to the development of architecture in this era. The special features of the architecture and decorations of buildings in Muzaffarid era led to the creation of a local school of thought, or style, of architecture. It is called Muzaffarid school of thought or Yazdi style (Wilber,1955, p.101). The distinctive feature of the Muzaffarid style was the use of "large transverse arches" supporting "barrel vaults" such as those added to the mosque at Yazd (Petersen, 1996). Muzaffarids made a sizeable

\footnotetext{
* Corresponding author
} 
number of personal and charity buildings especially in Yazd, Meybod, and Ardakan some of which still exist. Although the Muzaffarid rulers did not earn the type of fame that makes their names universally known, the dynasty did give its name to culture and architecture.

\section{MATERIALS AND METHODS}

\subsection{Geographical and Historical area of study}

The geographical area of this study is Ardakan County, which is the second major city of Yazd Province located on the north side of the province and in the middle of the central desert of Iran (Figure 1). The proximity of Ardakan to the central desert of Iran has led to the high effect of desert weather on this region; winters are cold with low precipitation and the summers are hot and dry. The per capita of precipitation is $62.9 \mathrm{~mm}$ and the average temperature is 20.2 degrees. Lack of water is one of the most serious limitations in the city.
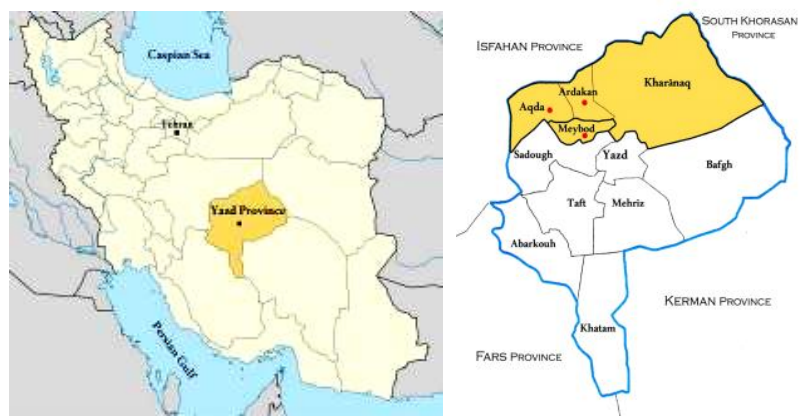

Figure 1. Location of Yazd Province in Iran; Location of Ardakan city in Yazd Province.

In Muzaffarid era, Ardakan was one of the villages of Meybod city (Kateb, 1966, p. 160) and the 14th century was one of the most decisive years for Ardakan due to the ruling of Muzaffarids in Meybod during which construction boomed. Generally; being located in the center of Iran and far from the boundaries, partial and consecutive security throughout the history of the region, benefiting from conservative peaceful rulers, dry and unfavorable weather, and being protected from natural disasters like flood and earthquake have saved the region from subversive happenings and made Ardakan county be protected from some of the rare samples of architecture in this era (Zakerameli, Jebelameli, 2013, p. 105). In figure 2, the historical urban fabric of Ardakan and the location of the four houses mentioned in the study are shown.
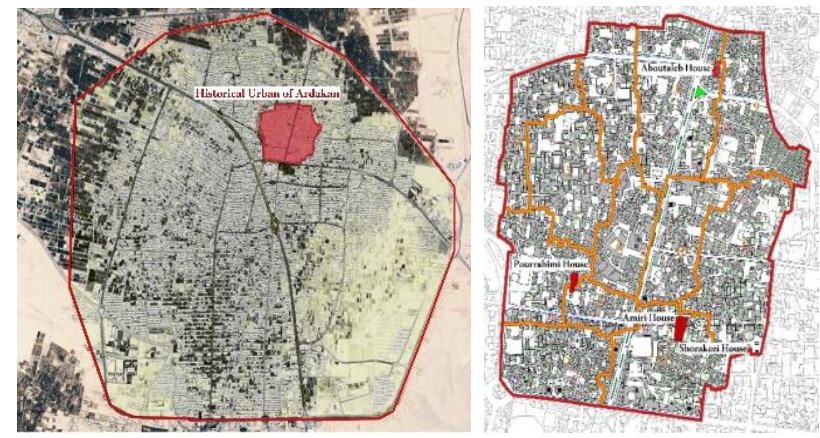

Figure 2. Location of historical urban fabric in Ardakan city; Distribution of studied Muzaffarid houses in historical urban fabric of Ardakan.

\subsection{Methodology}

By definition, typification is the action of typifying, i.e., dividing/distinguishing into types. The concept of type refers to the overall or the set of properties common to some individuals or objects recognizing structural similarities between architectural objects (Santos et al., 2013). According to Petruccioli (1999), a type is the organic ensemble of the common characteristics of buildings in a defined culture over a specific period. The methodology used involved quantitative and qualitative analysis of the building typology of Muzaffarid houses in Ardakan. In this study, understanding the location and position of spaces and architectural elements especially unique spaces of the Muzaffarid houses including Iwan, Soffeh, and garden were intended. To do so, by using a descriptiveanalytical research method and studying the spatial organization diagrams as well as studying literature review and field studies; the typology of 12 houses is recognized. Four of these houses were thoroughly analyzed according to fundamental spaces, materials, construction techniques, and decorations. Also, the various spatial characteristics are clarified by the use of graph representation, dimensionless plans, and axial diagrams.

\section{RESULTS AND DISCUSSION}

\subsection{Mozaffarid Houses in Ardakan}

Some parts of the Muzaffarid cultural heritage, which are of high importance in architectural features and are identified in some historical neighborhoods of Ardakan city are Muzaffarid houses. The houses in this era, as the oldest remained houses in Iran, reveal the construction pattern formed in the 14th century, which continued until the Safavid dynasty. The general pattern of studied houses has been repeated despite some differences in the location of spaces. All of these houses are built around a small central courtyard. There is an Iwan in one of the southern or northern sides of the central courtyard and on the opposite side, there is a Soffeh. On the east and west sides, there are 2 small Soffehs and two doorways. One of the doorways connects the entrance corridor to the courtyard and the other one is the doorway of a room. In the back part of the main Iwan, there is a Tanabi room or a garden and on each eastern and western side of that, there are rooms in two stories. Since visual protection is critical because of privacy, attention is also given to the patterns of entry and access to and from the central courtyard. In table 1, the data regarding all identified Muzaffarid houses in Ardakan have been displayed. This table consists of the information about all samples of the investigation. In these diagrams, the main parts such as semi-open spaces (Soffeh and Iwan), open spaces (the central courtyard and garden), and close spaces such as service spaces, living spaces, and adjunct spaces have been shown by using different colors. The vertical axis represents the northeast-southwest direction.

\subsection{Architectural features (Spatial and Functional Organization)}

In this section, characteristics of site and main spaces as well as seven functional features of plan are analyzed and evaluated as it is shown in Tables 2 and 3. The most important spaces of investigated houses include entrance corridor and Pishgah (Entrance hall), Main Iwan, Soffeh (in front of Iwan), the space behind the Iwan (Tanabi or Soffeh), the courtyard and garden, and the western and eastern rooms. These houses usually lack the basement. 

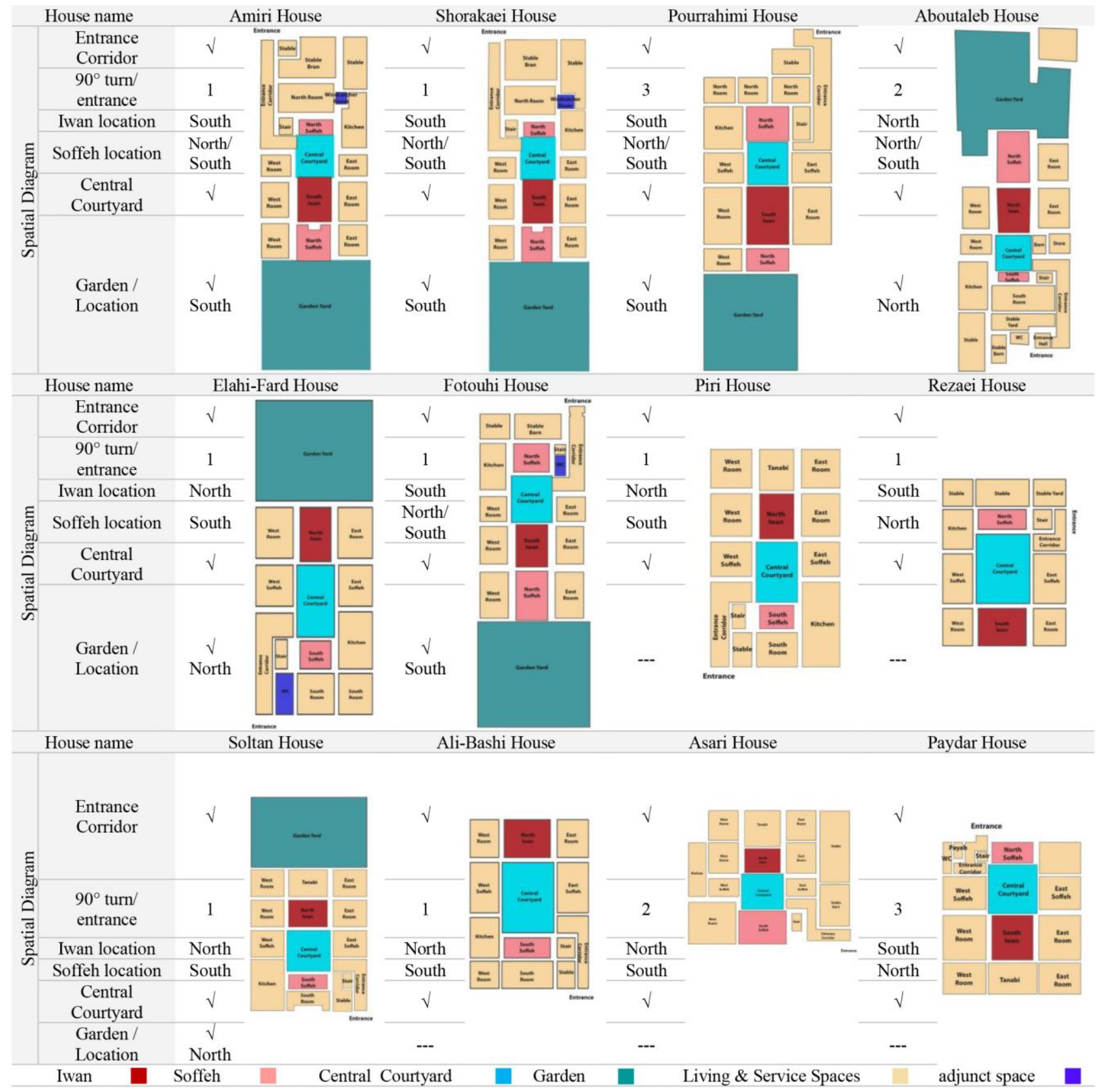

Table 1. Spatial organization diagram of the case studies of Muzaffarid Houses. Reference: Author.

- The Characteristics of the Site: In all investigated houses, except for Asari house, the land is rectangular and in the north-south axis with a 10 to 12 degree of deviation to east. This orientation in accordance with Roon Raste $^{1}$ in a way that the longer side of the land is in the north-south axis and the shorter is in the east-west axis. This orientation is predominant in the historical urban fabric of Ardakan. As well as different climatic factors, the orientation has been affected by the rules of farms and gardens irrigation network. As the lands in Ardakan has south to north slope, Qanats ${ }^{2}$ flow from south to north and the farmlands direction is the same (Zakerameli, Esfanjari Kenari, 2007, p. 165).

1 In Iranian architecture, Roon refers to the direction of the building. Roon Raste stands in the northeast-southwest direction.

2 A gently sloping underground channel to transport water from an aquifer or water well to surface for irrigation and drinking.
- Entrance Corridor and Pishgah: All these houses have a Pishgah. In some cases, however, the Pishgah has been destroyed or had a small area. The pishgah is often simple without much decoration. After the Pishgah, there is a corridor making it available to access service areas, stables, and staircase leading to the roof. With one or some 90-degree turns, the corridor connects the Pishgah to the central courtyard. The common point about all these houses is that one can enter the courtyard only from the eastern or western side of that.

- Main Iwan: Muzaffarid Iwan is the oldest Iwan in Iranian traditional houses remaining firm and stable until now (Zakerameli, Jebelameli, 2013, p. 203). This Iwan, which is known as the most important and outstanding architectural element in Muzaffarid houses is taller than Iwans of the upcoming eras and it forms a long vertical rectangle. The height of the Iwan is between 7 to 9 meters in the investigated houses, which is 2.2 to 2.8 larger than the span. 


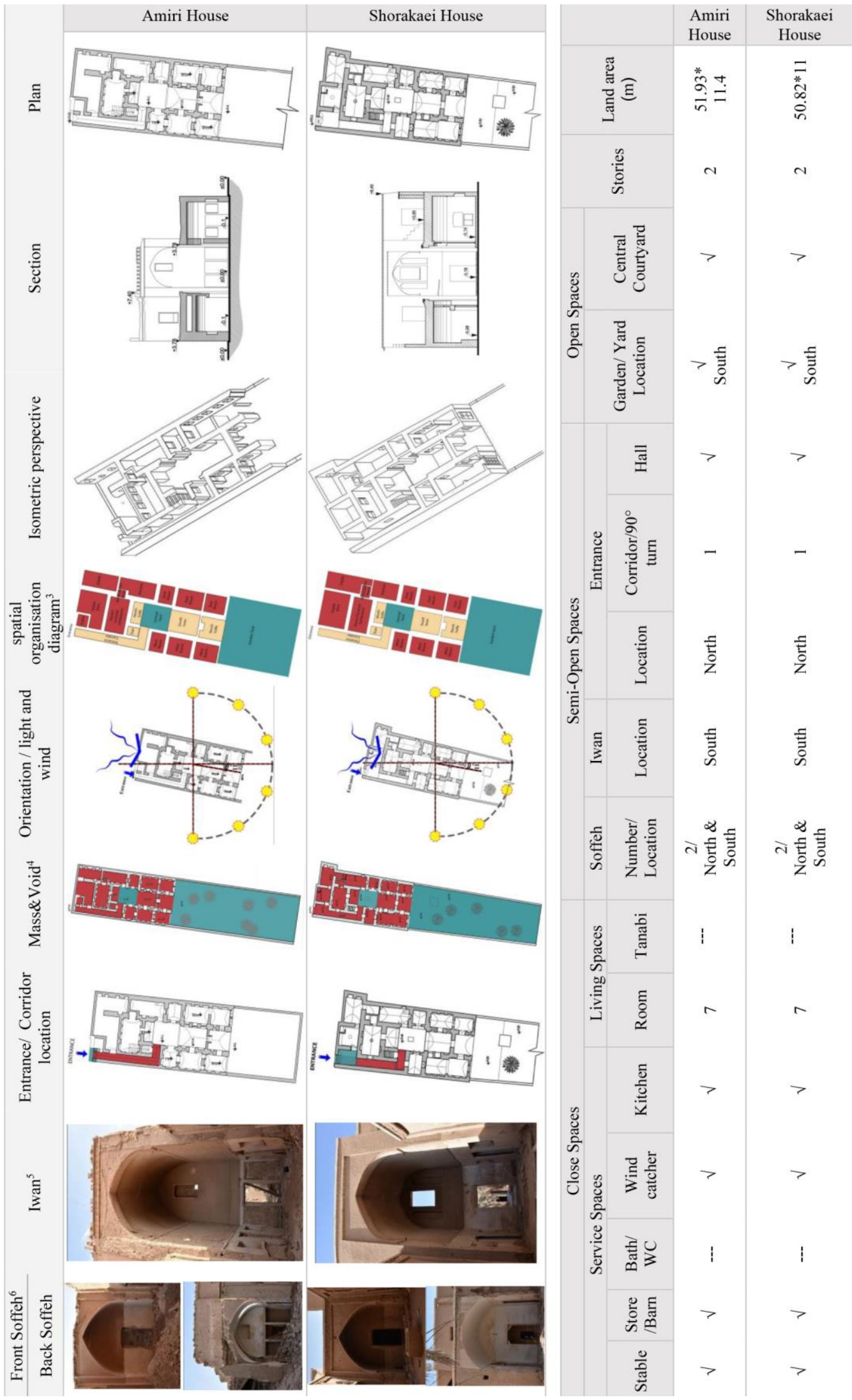

Table 2. Main Spatial and Functional characteristics of Amiri and Shorakaei Houses. Reference: Author.

3 Open Space \& Semi-open Space \& Closed Space (Blue, cream and red respectively).

$4 \quad$ Mass \& Void (Red and blue respectively)

\footnotetext{
5 Iwān (also written Ivān or Eyvān): A rectangular semi-open roofed space, usually vaulted, walled on three sides, with one end entirely open.
}

6 Shallow-porch are built on the first floor facing the courtyard. 


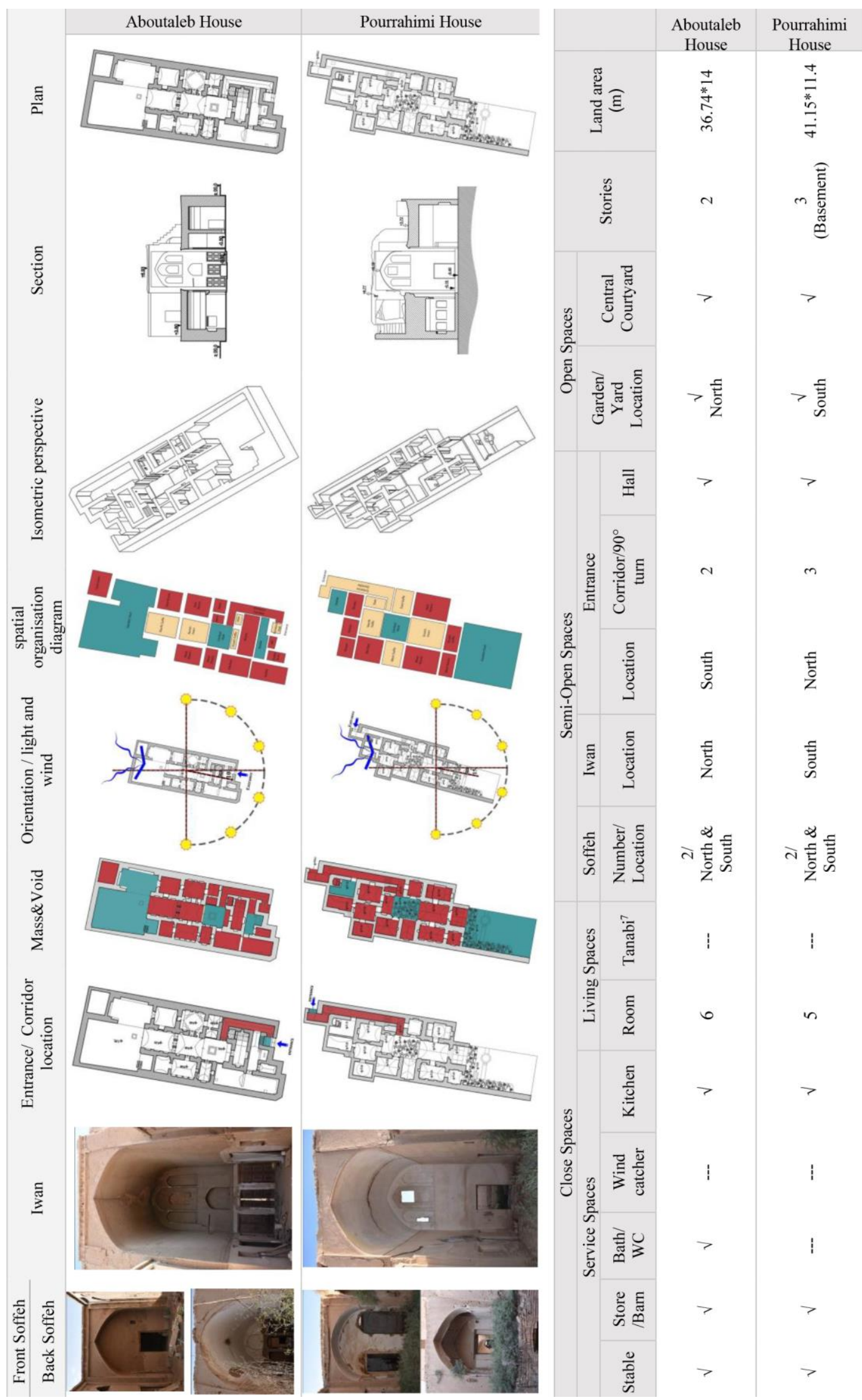

Table 3. Main Spatial and Functional characteristics of Aboutaleb and Pourrahimi Houses. Reference: Author.

\footnotetext{
7 The main decorated big hall where guests are entertained.
} 
The width of the Iwan is the same as the central courtyard and the depth is almost the same as the length of latter. The Iwan occupies almost the same area as the courtyard. The construction of Bâdgir (wind catcher) has not been common in the Muzaffarid era and these houses do not benefit from Bâdgir. The long narrow Iwan on the top of the small courtyard acts as natural ventilation and transfers the wind into the courtyard. However, in some houses, there are Badgir being built in the next eras. Iwan also acts as the divisionary space to access some of the areas.

- Soffeh in front of Iwan and the Room behind it: On the opposite side of the main Iwan, there is a small Soffeh accessing to which is possible through the door located on the Espar $^{8}$ of the Soffeh. Behind this Soffeh, there is a long room perpendicular to the courtyard. The height of this side of the house is at the same level as the western and eastern rooms.

- The space behind the main Iwan: In the investigated houses, the space behind the main Iwan is often a Tanabi or a Soffeh overlooking a garden on the north or south of the land. In some cases, there is no space behind the main Iwan. The entrance doorway to this area is located on the Espar of the Iwan.

- The rooms adjacent to the main Iwan: In the east and the west side of the main Iwan, there are two rooms, the accessibility to which is possible through the doorways located symmetrically on two side walls of the Iwan. These rooms are connected to the courtyard through Iwan and space lighting is provided by the doorway openings. In houses where behind the main Iwan is a Soffeh overlooking the garden, lighting of the rooms adjacent to the Iwan is provided by the rooms adjacent to this Soffeh. On top of these rooms, there are 2 more rooms on the first floor, which are at the same height as the Iwan. These rooms have a structural role and act as flying buttresses. They are mainly used as the food or goods depot and can only be accessed through the stairs in the entrance corridor. The west and the east spaces of Iwan, which are symmetrical are the only two-story part of the house.

- Yard: All of the studied houses are arranged around a central private courtyard where family activities occurred. In the whole area of the house, a small area is allocated to the central courtyard, which is almost 3 to 6 percent (Zakerameli and Esfanjari Kenari, 2007, p. 170). The central courtyard acts as the heart of the traditional dwelling and connects all spaces including closed, open, and semi-open to each other. None of the houses has a pond or flowerbed in the central courtyard. The whole spaces of the building can be accessed by a 20 -centimeter stair upper the central courtyard. The main concept behind designing the central courtyard house was to generate an inward-looking plan with plain external walls, which were designed to discourage strangers from looking inside the house as well as to protect the house from the harsh climate of the region (Edwards et al., 2006; Salama, 2006).

In some houses of this era, in addition to the central courtyard, there is a garden behind the main Iwan playing an important role in ventilating the house. In all these houses, the garden has palm trees with non-original ponds. This yard is located along the Iwan, the courtyard and the Soffehs and has emphasized the north-south axis of houses in Ardakan.

8 A wall which is built between two bearing walls; the end wall of the vault.

\subsection{Construction Method (Material and technique)}

This section presents a review of the construction systems and materials (Table 4). The materials used in Ardakan's Muzaffarid houses are totally in harmony with the hot and arid climate. All windows and doors have been built of wood. The main building material of all houses is adobe and they are constructed based on load-bearing walls. In addition to the load-bearing role of thick walls, the width of the walls acts as a thermal mass, getting solar energy during the day and giving it back during the night to create a balance in temperature. In the architecture of Muzaffarid houses in Ardakan, vault structural systems have been common. Arched ceilings, in a variety of shapes (vaults, arches, Tavizeh ${ }^{9}$ ), have often been used, which were rarely decorated with the patterns. Also, Karbandy ${ }^{10}$ was used in transferring the area of a dome in one house (Aboutaleb House). The flat roof has been used sometimes in some parts such as in a barn (the room adjacent to the Iwan on the first floor, Amiri and Shorakaei house).

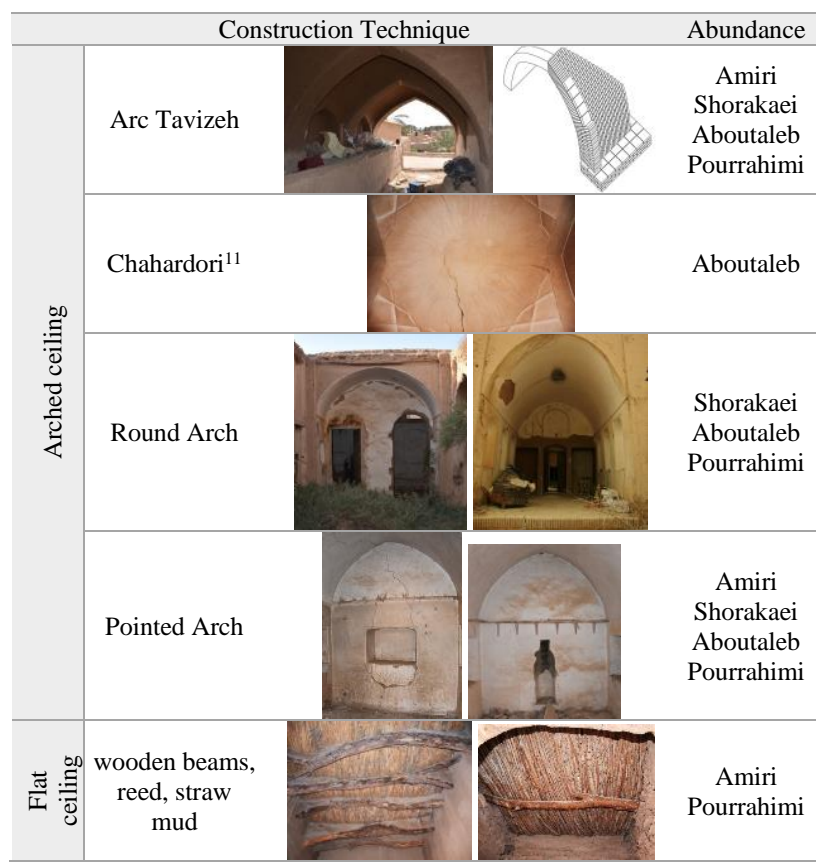

Table 4. Construction Method of 4 case studies of Muzaffarid Houses. Reference: Author.

\subsection{Decorative Features}

In the Muzaffarid era, housing some of which were highly decorated was flourished by the well-known citizens. Muzaffarid houses in Yazd have been decorated in different way, however, mud decorations have been of high importance in the houses. Some examples are mud wall sculptures and mud muqarnas $^{12}$ and shamseh ${ }^{13}$. Mud decorations have special delicacy and elegance, so they are just used in rare cases. The abundance of these decorations has not been the same in Yazd

9 The bearing strips of the arched ceilings to transfer the compressive loads to the side walls.

10 Or Ribbed Vault consisting of arches with geometric rules under the original cover intersect.

11 Chahardori vault is implemented on a square plan. The center of each side of the square is found and the resulted triangle on each side is covered with a large squinch to the hypotenuse.

12 A form of ornamented vaulting in Islamic architecture.

13 A symbolic and abstract representation of the sun running in circles or polygons. 
province and no evidence of the mud decorations has been found in Muzaffarid houses of Ardakan County. Different methods have been utilized to decorate Muzaffarid houses in Ardakan, which can be observed in most of the recognized houses (Table 5). A group of these methods is simple and basic including decorative strip frames under the arch's springing line, the use of Kali1 ${ }^{14}$ arches, and decorative Taghnama ${ }^{15}$ for vaults. The simplicity of implementation, which was possible with low cost and accessible tools, can be mentioned as the reason for prevalence of these methods. The other group is not as common as the first, although it is seen in some cases. Among the investigated cases, using gypsum decorations (such as lattice windows and decorative frames), wooden lattice windows, and karbandi can be placed in this category.

\begin{tabular}{|c|c|c|}
\hline \multicolumn{2}{|r|}{ Decorative element } & Abundance \\
\hline 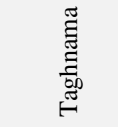 & & $\begin{array}{c}\text { Shorakaei, } \\
\text { Aboutaleb, } \\
\text { Pourrahimi } \\
\text { Houses }\end{array}$ \\
\hline 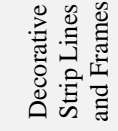 & & $\begin{array}{l}\text { Amiri, } \\
\text { Shorakaei } \\
\text { Houses }\end{array}$ \\
\hline 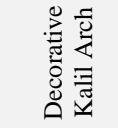 & & $\begin{array}{c}\text { Amiri, } \\
\text { Shorakaei } \\
\text { Houses }\end{array}$ \\
\hline 岂泀 & & $\begin{array}{c}\text { Shorakaei } \\
\text { House }\end{array}$ \\
\hline 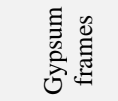 & & $\begin{array}{c}\text { Aboutaleb, } \\
\text { Pourrahimi } \\
\text { Houses }\end{array}$ \\
\hline 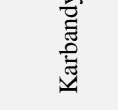 & & $\begin{array}{c}\text { Aboutaleb } \\
\text { House }\end{array}$ \\
\hline 蓄 & 111111111 & $\begin{array}{c}\text { Amiri, } \\
\text { Pourrahimi } \\
\text { Houses }\end{array}$ \\
\hline
\end{tabular}

Table 5. Decorative Features of 4 case studies of Muzaffarid Houses. Reference: Author.

\subsection{Building type classification}

According to the analysis of the Muzaffarid houses in Ardakan, it can be seen that the architecture and organization of spaces in these houses follow a general pattern. All of these houses consist of spaces including Pishgah and entrance corridor, a main Iwan, Soffeh in front of the Iwan, rooms on the eastern and western part, and a central courtyard. Also, historical architectural evidences show that the triple combination of the main Iwan, the central courtyard and the Soffeh in front of the Iwan with the north-south axis is repeated in all Muzaffarid houses of Ardakan. Other spaces of the house have been formed surrounding them. The common architectural pattern of these houses is introvert due to the central courtyard. Some houses

\footnotetext{
14 A low-height Iranian arch, a combination of Mazehdar and Tizehdar arch.

15 False arch, having the appearance of an arch though not of arch construction.

16 An Iranian Pattern, Special technique in the material arrangement.
}

have a garden too, which is on the back of the main Iwan; thus, they have a semi introvert-semi extrovert pattern. Other general characteristics of this houses can be extended to the elongation of the building in Roon Raste direction, a mass of building in four geographical directions, the two-story part on the west and the east sides of the Iwan, a courtyard level close to the public passage level, multiple 90 degrees turns in the entrance corridor for security and privacy, a rectangular courtyard and rooms, the use of three types of open, semi-open and closed spaces, the installation of windows and openings facing the central courtyard, not using of pond and plants in the courtyard and also the use of Tizehdar ${ }^{17}$, and in some cases, Mazehdar ${ }^{18}$ arches. In addition, the use of local materials and conformity of architecture and structure with climate are also significant in the houses of this period.

As the typology defines the most fundamental differences, the spatial types of the studied houses can be distinguished based on the location of the Iwan in the northern or southern side of the central courtyard and presence or absence of a garden behind the Iwan. Therefore, Muzaffarids houses in Ardakan can be classified into two main types each of which can be divided into two subcategories according to the location of the Iwan (Table 6).

The first type has both a central courtyard and a garden as well as a Soffeh behind the Iwan which faces the garden. This type benefits a Soffeh with natural ventilation due to the extensive vegetation in the garden, rooms in the western and eastern parts of the Soffeh overlooking the garden with natural lighting and thus better spatial quality in the adjacent garden spaces. This type involves two subcategories: in the first subcategory, the Iwan is in the south of the central courtyard, the garden in the south of the land, and the Soffeh - which is facing the garden- is in the south of the Iwan and the north of the garden. In the second subcategory, Iwan is located in the north of the central courtyard, the garden is in the north of the land and the Soffeh is in the north of the Iwan and the south of the garden. In the Second Type, there is no garden and a Tanabi room or an ordinary room is often located behind the Iwan. However, sometimes there is no room. This type has a very compact plan with minimal natural lighting and natural ventilation through the small central courtyard.

Table 6 summarizes the research findings. The first and second rows indicate the position of the main Iwan and the garden as fundamental differences. The other rows are spaces present in all samples, but due to different positioning, they have caused changes in the spatial organization of the plans.

\section{CONCLUSION}

In this study, it is shown that the Muzaffarid houses in Ardakan have distinct and identifiable patterns that distinguish them from those of other historical eras. Main Iwan is the fundamental space of these houses that is prominent in all patterns. According to the location of the Iwan and the garden, Muzaffarid houses in Ardakan are classified into two types. Due to the existence of the garden, the first type has a larger area and a better spatial quality as well as more decorations and sometimes more varied construction techniques. These houses probably belonged to well-off families with better financial status and higher social-economic backgrounds in the Muzaffarid era. The second type has less area and less spatial

\footnotetext{
17 Equilateral pointed arch

18 Round arch
} 
quality and diversity than the first type. This type consists of fewer open and semi-open spaces, so it uses less natural ventilation and sunlight. More limited decorations and construction techniques are also observed. The analysis of the Muzaffarid houses within the city of Ardakan conveys that not only the climatic factors but also cultural-social values have defined the housing typology or the spatial organization of the studied house. Thus, the housing evolution represents a collective development reflecting both the cultural needs as well as the various environmental constraints. These traditional houses represent a spontaneous model that refers to a humble experience of local skills and the limitation of the available local construction materials. Nevertheless, it is widely acknowledged as a distinctive example of a housing development that perfectly confronts the harsh desert climate and responds adequately to the basic needs of its users.

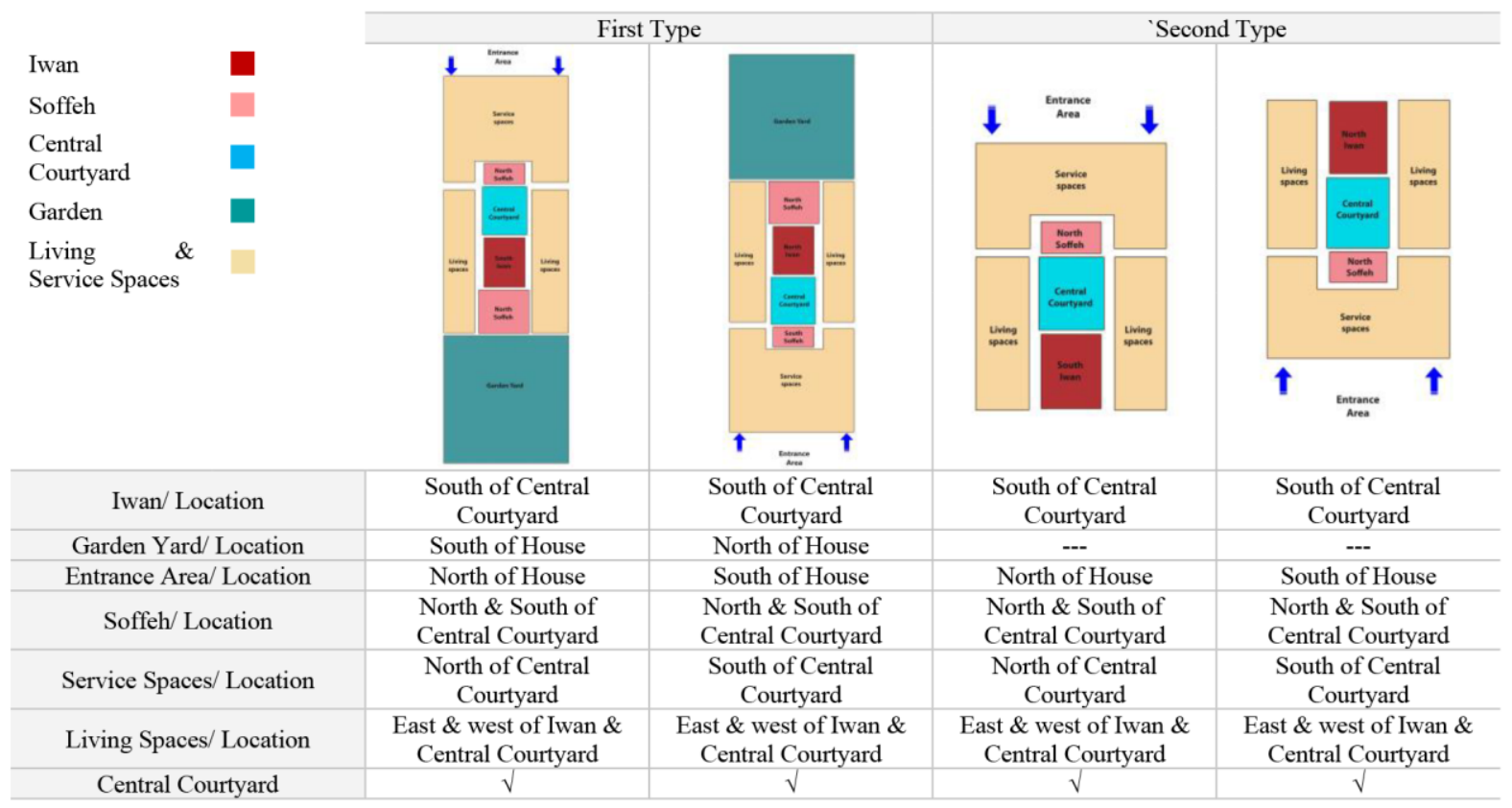

Table 6. Classification of typologies of Ardakan Muzaffarid Houses. Reference: Author.

\section{REFERENCES}

Ayati, A., 1938. Tārik-e Yazd yā Ātaškada-ye Yazdān, Yazd, Iran.

Edwards, B., Sibley, M., Hakmi, M., Land, P., 2006. Courtyard housing: past, present and future. Taylor \& Francis Group, New York.

Fisher, W.B., Gershevitch, I., Yarshater, E., Frye, R.N., Boyle, J.A., Jackson, P., Lockhart, L., Avery, P., Hambly, G., Melville, C., 1968. The history of Iran. Cambridge, UK: Cambridge University Press. ISBN 9789004127562.

Kateb, A., 1966. The New History of Yazd. By the efforts of Iraj Afshar. Tehran: Iran Culture.

Manz, B.F., 2007. Power, politics and religion in Timurid Iran. Cambridge, UK: Cambridge University Press. ISBN 9780521865470.

Mirhosseini, S.H., 1993. Yazd from the rise to the fall of Muzaffaris. Master thesis. History field. Faculty of Literature and Humanities, University of Tehran.

New World Encyclopedia contributors. (2009). "Muzaffarids," New World

Encyclopedia, //www.newworldencyclopedia.org/p/index.php?ti tle=Muzaffarids\&oldid=915345 (accessed January 24, 2020).

Petersen, A., 1996. Dictionary of Islamic architecture. London, UK: Routledge. ISBN 9780415060844.
Petruccioli, A., 1999. Historical Processes of the Building Landscape, Architectural Knowledge and Cultural Diversity, ed. W. O'Reilly, Comportements, Lausanne, Switzerland; 3950.

Salama, AM., 2006. A typological perspective: the impact of cultural paradigmatic shifts on the evolution of courtyard houses in Cairo. METU J Fac Archit, 23(1):41-58.

Santos, C., Miguel Ferreira, T., Vicente, R., Mendes da Silva, J.A. R., 2013. Building typologies identification to support risk mitigation at the urban scale Case study of the old city centre of Seixal, Portugal. Journal of Cultural Heritage, 14: 449-463.

Turner, J. (1976). Housing by people. Marion Boyars, London. Wilber, Donald. (1955). The Architecture of Islamic Iran: The Il Khānid Period, Princeton.

Wing, Patrick, "MOZAFFARIDS", Encyclopeædia Iranica, online edition, 2014, available at http://www.iranicaonline.org/articles/ mozaffarids (accessed on January 24, 2020).

Zakerameli. L, Esfanjari Kenari. E., 2007. Muzaffarid houses of Meybod. From the book of "A city there is in Meybod". By Eisa Esfanjari Kenari. Tehran: Cultural Heritage, Handicrafts and Tourism Organization of Iran, Meybod Cultural Heritage Research Institute.

Zakerameli, L., Jebelameli, A, 2013. Investigating the evolution of Iwan in traditional houses of Yazd-Ardakan plain from Muzaffarid to Qajar era. Soffeh Journal. No. 62. 